\title{
Postmodernism and Educational Research
}

\author{
Madelaine Campbell \\ The University of Victoria, Victoria, Canada \\ Email: madelaine.campbell@viu.ca
}

How to cite this paper: Campbell, M. (2018) Postmodernism and Educational Research. Open Journal of Social Sciences, 6, 67-73.

https://doi.org/10.4236/jss.2018.67006

Received: June 7, 2018

Accepted: July 15, 2018

Published: July 18, 2018

Copyright $\odot 2018$ by author and Scientific Research Publishing Inc. This work is licensed under the Creative Commons Attribution International License (CC BY 4.0).

http://creativecommons.org/licenses/by/4.0/

\begin{abstract}
Postmodernism is an elusive concept when we attempt to connect it to educational research methodologies. This paper is a review of the literature regarding postmodernist research methodologies in education.
\end{abstract}

\section{Keywords}

Postmodernism, Educational Research, Research Methodology, Postmodernist Research Methodology, Researcher Identity Formation, Education, Higher Education, Discourse Analysis, Critical Discourse Analysis

\section{Introduction}

Postmodernism in educational research typically reveals itself through the methods of Discourse Analysis (DA), (Lee \& Petersen, 2000) [1] and Critical Discourse Analysis (CDA), (Wodak \& Meyer, 2009) [2]. The generally accepted definition of postmodernism is well described by Zeeman, Poggenpoel, Myburgh \& Van der Linde (2002) [3] who write, "Postmodern theory sets about dismantling most of our normal ways of thinking about how meaning interpretation and reality works. This dismantling process is also visible in education and educational research" (p. 96). They further explain that discourse analysis has its roots in other social sciences, namely literary studies, anthropology, and linguistics (p. 97). In addition, Rogers, Malanchurvil-Berkes \& Mosley (2005) [4] extrapolate how ten years of educational research manifested in CDA so educators could better understand educational environments (p. 366). Furthermore, Edwards \& Usher (2002) [5] examine the difficulty of placing education within a postmodernist context because the foundation of schools was based on modernist principles. Because the theory underlying DA and CDA has been influenced by postmodernists such as Foucault (1975) [6], Fairclough (1989) [7], Lacan (1977) [8], Lyotard (1978) [9], and Derrida (1976) [10] whose works stemmed as a reaction to modernism and rational empiricism, which is the underpinning phi- 
losophy of traditional education, the focus of this paper is on postmodernism in educational research rather than poststructuralism. As noted by Diez and Da Costa (2011) [11], poststructuralism is ultimately related to postmodernism. They write, "Poststructuralism is a particular style of analysis within postmodern thought more generally" (para 4).

The purpose of this paper is to reflect upon and examine postmodernist research methodology in educational contexts looking specifically at DA and CDA.

\section{Theories about Postmodernism and Education}

Describing postmodernism in educational contexts is difficult, mainly because the purpose of postmodernism is to question and deconstruct the scientific empirical rational model under which schools as we know them were developed (Edwads \& Usher, 2002, p. 2) [5]. Public schooling in the 20th Century resulted from underlying vested interests, namely in Canada shortly after confederation, for securing a sense of nationalism and loyalty of its citizens, who were rebellious in spirit and prone to covert uprisings (Gaffield, 2013, p. 4) [12]. In the United Kingdom during the Industrial Revolution, the purpose of schools was to train law abiding factory workers (Bartlett, 2016, p. 72) [13]. Sadly, nouveau ideals about educating children for the love of learning, as exemplified by Dewey (1905) [14]-brewed as a reaction to the factory formulation of education-were undermined by overarching political interests such as Sputnik STEM reforms where the focus of education turned to an emphasis on physics, math and science in order to compete with other nations for domination of space exploration (Clowse, 1981) [15]. So, it is obvious that schools served a purpose, and postmodernism in essence serves to analyze the systems under which they arose. Edwards \& Usher (1994) [5] explain that the influence of the postmodern movement on education, is not to prescribe new rules for educators or students, but instead is a method for looking at education more critically. They write, "It may suggest a way of looking differently at education as a social practice, at educational processes such as learning and teaching, and at bodies of knowledge and the ways they are organized and transmitted (p. 28).

Because, as Edwards \& Usher write, the purpose of postmodernism in education should be as a tool to reflect upon and examine underlying systems from which schools and universities have arisen, it becomes necessary to review some of the theorists who present postmodernist ways of thinking. From an epistemological perspective, there are a group of theorists who can be classified as postmodernist who interrogated modernism, and resultingly, challenged rational empiricism.

Lyotard [9] coined the term "postmodernism" in his 1979 book, La Condition Postmoderne. in which he identifies the separation of tribal wisdom from scientific knowledge; knowledge which was emblematic of the modernist period. $\mathrm{He}$ explained that science was legitimated through meta-narratives, and postmo- 
dernism sought to question those stories. Foucault (1975) [6] analyzed institutions as systems of power where authoritative forces subsume control; therefore, legitimizing narratives of power. Similarly, Lacan (1977) [8] identified from a psychoanalytical perspective that speech and language exchange affected the subject, and as humans, we are in a constant state of flux because of language. His ideas were postmodernist in that he saw people as leading non-linear lives, and this idea opposed the linearity of the grand narratives that dominated modernism. In addition, Derrida (1976) [10], was incremental to postmodern thought through his deconstruction of text, where he argued that the meaning of words and their assertions of power require critique. Ten years after Derrida's work, Fairclough (1989) [7] wrote Language as Power where he created the method of CDA due to the necessity for analyzing language and its impact on social meaning for the purpose of research. He has gone on to create "Political Discourse Analysis", which deals with political language specifically, and has been a previously understudied area (Finlayson, 2013) [16]. These theorists provided essential frameworks for deconstructing language, power differentials, and institutionally formed value systems. Their theoretical frameworks, therefore, influence postmodernist educational research. Critical discourse analysis and discourse analysis are two methods that resulted out of postmodernism as a means of critically questioning power dynamics, structures, and their consequent discourses, which is necessary for educators to embrace as we continue to examine the function of education.

\section{Educational Research in the Postmodern}

Typically, two main forms of educational research methods have been identified as postmodern: discourse analysis (Lee \& Petersen, 2011) [1], and critical discourse analysis (Wodak \& Meyer, 2009) [2] although postmodernism is not only limited to these two educational research methods, as exemplified by Brown \& Jones (2001) [17] who write about postmodernist action research. According to Lee \& Petersen (2011) [1], DA is postmodernist in that it involves two prominent features which they describe as a: "radical questioning of the nature of knowledge" (p. 139) which requires a "social analysis of the increasing textualization of the modern world" (p. 140). Wodak \& Meyer (2009) [2] explain that $\mathrm{CDA}$ is postmodernist in its questioning of the relationships between language and power (p. 2).

I will first explain CDA and DA, and go over some of the literature, and then I will provide a general literature review of postmodern research methodology.

According to Jorgenson and Phillips (2002) [18], "discourse" can be defined as follows, "a particular way of talking about and understanding the world (or an aspect of the world)" (p. 1). Therefore, its analysis would be to examine text, be it spoken word, written, typed, or images. And they point out that rather than being one type of method, it is interdisciplinary in nature, and there are no clear definitions as to what constitutes "text". Davis and Lester (2016) [19] for exam- 
ple, use discourse analysis to analyze the discussions of graduate students who are asked how they form their research identities. They use the "Discursive Psychology" framework of Edwards \& Potter (1993), and the "Conversation Analysis" framework of Sacks (1992), as their interdisciplinary focus of analysis. Traditionally, in an educational context, Rogers, Malanchuruvil-Berkes \& Mosley (2005) [4] explain that educators most commonly use discourse analysis to analyze "educational talk" (p. 366), although earlier studies predominantly focused on written text, and more recent research is trending toward the analysis of classroom "talk". They note that in the ten years of educational research, $66 \%$ of the studies involved interactional language, and educators view discourse analysis as a means of navigating educational environments. They write, "Education researchers turned to discourse analysis as a way to make meaning in educational contexts" (p. 366). The difference between discourse analysis and critical discourse analysis is that the former could be considered more benign, and the latter more of a critique. According to Wodak \& Meyer [2], CDA has a purpose that is to analyze a particular problem in its relation to power structures. They write, "This research specifically considers institutional, political, gender and media discourses (in the broadest sense) which testify to more or less overt relations of struggle and conflict" (p. 1). CDA in education, as Rogers, Malancharuvil-Berkes \& Mosley (2016) [4] explain, allows for an analysis of oppression in educational contexts, although they suggest that more studies should focus on discourses of "liberation" rather than only on "oppression", as this area was limited in scope (p. 384). Similarly, the authors noted that primary schools were sorely underrepresented in the studies. They conclude with some important recommendations as to how $\mathrm{CDA}$ in educational research can be improved in the future. First, they noted that although the researchers included multiple analytic methods, they failed to utilize multiple framework models, with the majority adhering to one. They write, "Many of the studies draw on Fairclough's approach-rather than on the approaches of van Dijk, Wodak, Kress and Van Leeuwen, and so forth" (p.386). Also, they found there was a missing link between linguistic resources and social practices. In addition, they noted a general lack of reflexivity in the studies, which is an important thread weaving through postmodern methodology. Brown and Jones (2001) [17] for example, show how action research, typically considered to be associated with the critically reflexive paradigm, becomes postmodernist when a reflexivity technique is added; their chosen method is reflective narrative, which they use as reflective narrative journals and these journals act to triangulate their data as teacher researchers. Rogers, Malancharuvil-Berkes \& Mosley (2016) [4] additionally note that the CDA they reported on, lacked a connection between the research findings, and "emancipatory action". They write, "We reported that very few of the articles reviewed here moved toward emancipatory action with the results of their analyses" (p.387). As Edwards \& Usher (2002) [5] argue, however, the idea of research being "emancipatory" is highly problematic because of its underlying oppressive traditions. They write, 
"Part of our 'project' has been to problematize the very notion of emancipation in the project of modernity and to show its oppressive assumptions and consequences, particularly in and through education" (p. 4). So, rather than assuming that CDA ought to be emancipatory, perhaps a better recommendation for CDA researchers would be that they provide a more detailed analysis of how the data collected can be of benefit or detriment to an educational environment. Overall, the most important piece, and what defines research as being postmodern, is the capability of the researcher to be overtly reflexive around their own biases as researchers. Scheurich (2001) [20] suggests that we can frame our postmodern research methods according to an in-depth analysis of bias, through his own methods called "Policy Archaeology" (pp. 97-98) and "Coloring Epistemologies" (p. 133). He writes, “we are unknowingly enacting or being enacted by 'deep' civilizational or cultural biases, biases that are damaging to other cultures and to other people who are unable to hear them because they do not 'speak' in our cultural 'languages"' (p. 1). Therefore, through policy archaeology, he asserts the necessity to examine social problems before they are named or constructed as such (pp. 97-98). He explains that feminists, or racial minority activists have very differing views of what constitutes normalcy in comparison to those views of state professionals or government agencies, whose quantified and visible constructions promote ideologies that become the normative standards for the general public to regulate. This is problematic because what he refers to as the "network of regularities" (p. 100), constitutes what "socially legitimized" (p. 100) policy issues might be solved, leaving out all of the unestablished problems that simmer beneath the sheen of prescribed normative social debate. In addition, he explains that research epistemologies are both overtly and covertly racist (p. 133), and because modernism was a predominantly white, male construction, its philosophies and modes of thought still dominate the larger culture. It is through being critical and reflexive of these overt and covert levels of bias, that we can elucidate insight from research in the social sciences.

In terms of higher education, postmodernism is a lens through which we can examine policy documents, as exemplified by the work of DiLeo (2017) [21] who uses DA and CDA to analyze journal databases search criterion of the words “academic habitus" (p. 68). Using the EBSCO system, DiLeo forms his argument on the basis of the examination of how neoliberal discourse is framing higher education in the United States, and throughout the world. He finds that searches for the term "academic habitus" have increased substantially since 2012, evidencing the sociocultural divide that corporatist influences in higher education have caused-perpetuating the legacy of who can afford and attend university. He writes, "Last year alone almost 10,000 pieces of research and scholarship on academe utilized habitus-and over 30,000 in the past five years. Given the basic characteristics of habitus, it is no wonder that resistance to change in academe is so strong and seems so difficult and distant" (p. 73). "Habitus", according to Bourdieu (1977) [22] refers to the sociocultural identity that is formed by one's 
place, or family's place in society, along with his or her status, which has been reinforced through social conditioning (Edgerton \& Roberts, 2014, p. 195) [23]. In addition to the field of higher education, Efe \& Ozer (2015) [24], use CDA to analyze the vision and mission statements of 105 state and 66 private universities in Turkey, in order to ascertain how global corporatist agendas have influenced their formation. The research revealed that all of the universities and colleges shared the same language in their mission statements, regardless of status. Similarly, they found that the language used reflected an overarching interest in marketing their country globally. They write, "since the inception of modern Republic of Turkey, Turkish universities have played a significant role the top-down modernization of the country. Universities appear to be the agents of the education process insofar as the passivation strategies" (p. 1120). So, CDA \& DA are significant methods used in higher educational policy analysis, but as evidenced by the research on postmodernism in educational research, there are no restrictions or limitations regarding the age level or type of educational setting required to examine discourse.

\section{Conclusion}

Using postmodernist research methods in educational research, we can take into consideration the recommendations of Rogers, Malancharuvil-Berkes \& Mosley (2016) [4] as to how critical discourse analysis can be improved within educational settings, while also incorporating some of Schleurich's (2001) [20] ideas around how to be reflexive of bias. Similarly, as Edwards and Usher (2002) [5] argue, becoming less attached to the idea of research as being emancipatory, and more interested in performing research in order to elucidate information rather than to transform people, is a postmodernist construct. In conclusion, postmodernist research is interdisciplinary, reflexive, and conscious of bias. Postmodernism is related most commonly to DA and CDA, but can be incorporated into other educational methods including action research (Brown \& Jones, 2001) [17].

\section{References}

[1] Lee, A. and Petersen, A. (2000) Discourse Analysis. In: Somekh and Lewin, Eds., SAGE, Los Angeles.

[2] Wodak, R. and Meyer, M. (2009) Introducing Qualitative Methods: Methods of Critical Discourse Analysis, SAGE Publications Ltd, 1-13.

[3] Zeeman, L., Poggenpoel, M., Myburgh, C. and Van der Linde, N. (2002) An Introduction to a Postmodern Approach to Educational Research: Discourse Analysis Project Innovation (Alabama).

[4] Rogers, R., Malancharuvil-Berkes, E. and Mosley, M. (2005) Critical Discourse Analysis in Education: A Review of the Literature. Review of Educational Research, 75, 365-416. https://doi.org/10.3102/00346543075003365

[5] Edwards, R. and Usher, R. (2002) Postmodernism and Education. Routledge. http://www.myilibrary.com?ID=32013 
[6] Foucault, M. and Sheridan, A. (1995) Discipline and Punish: The Birth of the Prison. Second Vintage Books Edition, Vintage Books, New York.

[7] Fairclough, N. (2001) Language and Power. 2nd Edition, Longman, Harlow, Essex, England, New York.

[8] Georgin, R. and Lacan, J. (1977) Lacan: Théorie et pratiques. Éditions L'Age d'homme, Lausanne.

[9] Lyotard, J.F. (1984) The Postmodern Condition: A Report on Knowledge. (No. 10).

[10] Derrida, J. (1976) Of Grammatology. 1st American Edition, Johns Hopkins University Press, Baltimore.

[11] Diez, T., Bode, I. and Da Costa, A.F (2011) Theory Concept: Postmodernism and Poststructuralism. In: SAGE Key Concepts. Key Concepts in International Relations, SAGE Publications Ltd., London, 167-172.

[12] Gaffield, C.R. (2013) History of Education in Canada. The Canadian Encyclopedia. http://www.thecanadianencyclopedia.ca/en/article/history-of-education/

[13] Bartlett, S. and Burton, D. (2016) Introduction to Education Studies. Sage.

[14] Dewey, J. (1905) The School and Society. United States.

[15] Clowse, B.B. (1981) Brainpower for the Cold War: The Sputnik Crisis and National Defense Education Act of 1958. Greenwood Press, Westport, Conn.

[16] Finlayson, A. (2013) Symposium on Isabela Fairclough and Norman Fairclough, Political Discourse Analysis: A Method for Advanced Students. Political Studies Review, 11, 311-312. https://doi.org/10.1111/1478-9302.12022

[17] Brown, T. and Jones, L. (2001) Action Research and Postmodernism: Congruence and Critique. Open University Press, Philadelphia.

[18] Jørgensen, M. and Phillips, L.J. (2002) Discourse Analysis as Theory and Method. SAGE Publications Ltd., London, 1-23. https://doi.org/10.4135/9781849208871

[19] Davis, C.A. and Lester, J.N. (2016) Graduate Students' Construction of Researcher Identities Explored through Discourse Analysis. Qualitative Research in Education, 5, 49. https://doi.org/10.17583/qre.2016.1473

[20] Scheurich, J.J. (2001) Research Method in the Postmodern. RoutledgeFalmer Press, London, Philadelphia.

[21] Di Leo, J.R. (2017) Higher Education under Late Capitalism: Identity, Conduct, and the Neoliberal Condition. Palgrave Macmillan, Cham.

https://doi.org/10.1007/978-3-319-49858-4

[22] Bourdieu, P. (1977) Outline of a Theory of Practice. Cambridge University Press, New York, Cambridge. https://doi.org/10.1017/CBO9780511812507

[23] Edgerton, J.D. and Roberts, L.W. (2014) Cultural Capital or Habitus? Bourdieu and beyond in the Explanation of Enduring Educational Inequality. Theory and Research in Education, 12, 193-220. https://doi.org/10.1177/1477878514530231

[24] Efe, I. and Ozer, O. (2015) A Corpus-Based Discourse Analysis of the Vision and Mission Statements of Universities in Turkey. Higher Education Research and Development, 34, 1110-1122. https://doi.org/10.1080/07294360.2015.1070127 